Article

\title{
Lefebvre's Politics of Space: Planning the Urban as Oeuvre
}

\author{
Andrzej Zieleniec \\ Faculty of Humanities and Social Sciences, Keele University, Staffordshire, ST5 5BG, UK; E-Mail: a.zieleniec@keele.ac.uk
}

Submitted: 4 January 2018 | Accepted: 14 March 2018 | Published: 12 June 2018

\begin{abstract}
Henri Lefebvre's project, developed over decades of research produced a corpus of work that sought to reprioritise the fundamental role of space in the experience and practice of social life. His assertion that there is 'politics of space' provides a challenge to the planning and design of the built environment by emphasising the need to understand the complex of elements involved in 'the production of space'. Lefebvre's approach and his 'cry and demand' for a 'right to the city' reflects the fundamental focus and importance he imparts to the practices, meanings and values associated with the inhabitation and use of the social spaces of everyday life. It will be argued that planning and design theory and practice should seek to address more fully and incorporate Lefebvre's spatial theory as a means to reinvigorate and regenerate the urban as a lived environment, as an oeuvre, as opportunity for inhabitation, festival and play and not merely as a functional habitat impelled by the needs of power and capital.
\end{abstract}

\section{Keywords}

built environment; city; design; Lefebvre; oeuvre; planning; space; urban

\section{Issue}

This article is part of the issue "Urban Planning and the Spatial Ideas of Henri Lefebvre", edited by Michael E. Leary-Owhin (London South Bank University, UK).

(C) 2018 by the author; licensee Cogitatio (Lisbon, Portugal). This article is licensed under a Creative Commons Attribution 4.0 International License (CC BY).

\section{Introduction}

Henri Lefebvre is acknowledged as one of the main progenitors of the multi-disciplinary spatial turn in the geographical and social sciences. His seminal works on the production of space, the urban and the right to the city provides a means for analysing and understanding the complexity of the form, structure, organisation and experience of modernity. It also offers a critique and the possibility for a reconfigured approach to the planning, design and structure of the architecture and landscape of the city and the urban, the dominant spatial form under capitalism. It will be argued that an appreciation, understanding and knowledge of Lefebvre's spatial thinking is not only appropriate but essential in creating a more humane and inclusive sociospatial environment that contrasts with the increasing prioritisation of privatized and commodified public and social space. Lefebvre offers the possibility for the development and application of not only a critical but also a socially and politically committed planning design theory and practice, one that considers, incorporates and promotes the importance of mak- ing space to include the values, diverse practices and creative potential of everyday life to reimagine and remake the city. His plea for 'the right to the city' can thus be understood as a challenge to the hegemonic orthodoxy of the homogenising practices of planning, design, commerce, and the overarching concern with risk assessment and avoidance, surveillance, order and security, and the needs of capital to create conditions for maximising profit. His emphasis seeks a rebalancing of the right to inhabit and make space rather than be subject merely to a created functional habitat. Lefebvre provides a critical focus on how space is made and how it can be remade by and through social practice to become an oeuvre, a work of the art of everyday life. That is, who owns and makes space through planning and design must also provide opportunities for play, for festival, for the imaginative use of the public and social spaces of the city to ensure that it becomes a living space rather than a sterile monotony of function over fun, exchange over use value, profit over people. That is, to propose that architecture and urban governance, planning and design can and should provide opportunities for remaking the city as a more humane, 
accessible and liveable social space by understanding its social production. The following will address how Lefebvre's theory of the 'production of space', his other writing on the city and his explicit call for the 'right to the city' to reflect not only a more inclusive planning and design process but an understanding of the city and the urban as not only forms of functionalised space but also the social processes of those who use space. That is the inclusion and empowerment of the meanings, values, hopes and imaginations of urban citizens for whom the city is lived within and through more than merely the designed intentions of planned space.

\section{The Production of Space}

Lefebvre's seminal work The Production of Space (1991) has been highly influential in reprioritising space in interdisciplinary social scientific analyses. In various works on the city, space and everyday life (Lefebvre, 1971, 1977, 1987, 1995, 1996, 2003, 2004, 2009, 2014; Lefebvre \& Levich, 1987) he repeatedly asserts the need to have knowledge of space not only as an abstract principle, or a means for ideological and material control but also as the contested terrain in which everyday life and practices create meanings, values, signs and symbols. Influenced by his humanist Marxism, his critique and analysis of the urban and modernity under capitalism, Lefebvre stresses the need to consider the historical, social, political and economic context in which the complex of elements in the production of space is essential for understanding the experience, the consequences, as well as the survival of capitalism. His contribution to illuminating the fundamental importance of understanding and knowledge of space in the multidisciplinary sociospatial analysis of the urban and modernity has been explored, expanded and applied by a range of authors (see, Elden, 2001, 2004; Elden, Lebas, \& Kofman, 2003; Harvey, 1978, 1985, 1990, 2001, 2007, 2012; Kipfer, 2002; Merrifield, 1993, 2006, 2014; Shields, 1999; Zieleniec, 2007). However, with some exceptions (Coleman, 2015; Fraser, 2011; Stanek, 2011), there is scope and it will be argued a necessity for a more rigorous recognition of how his spatial theory, analyses and approach can be adopted, adapted and applied by planning and design practitioners.

In brief, Lefebvre's position can be laid out as follows. Space is not merely natural, material, a void waiting to be filled with contents. It is socially produced. For Lefebvre, it is both a product and a process of social activity that occurs within the structures and hierarchy of societies, increasingly subject to what he called 'an urban revolution' that continues to develop under capitalism. He states that his "analysis is concerned with the whole of practico-social activities, as they are entangled in a complex space, urban and everyday, ensuring up to a point the reproduction of relations of production (that is, social relations)" (Lefebvre, 1991, p. 73.) Space is produced from the relationship and interaction between a com- plex of factors and elements that prioritises how certain forms and structures of space can be linked to functions and how this impacts on the use of space in everyday life. Every society in every era produces its own space to meet its needs and priorities. It does so to ensure societal cohesion, functional competence, and to assert and maintain ideological and political power and control. Under capitalism space has come to be the dominant form by and through which production, consumption, reproduction and circulation are organised and structured, ultimately to meet the requirements of capital (see, Harvey, 1978, 2001). Space therefore is a material product and the means by and through which capitalism survives, but space is also simultaneously a process involving social relations between people and between people and things in space.

To understand space and its impact on the form, structure and lived experience of everyday life, Lefebvre identifies three necessary elements for the production of space:

- 'Spatial practices' (perceived space), which "structure daily life and a broader urban reality and, in so doing, ensure societal cohesion, continuity and a specific spatial competence" (Merrifield, 1993, p. 524). We need to 'know' space, how to navigate, be in and negotiate relations in space in a coherent and consistent way to make sense and function in the world;

- 'Representations of space' (conceived space), what Lefebvre calls the "space of scientists, planners, urbanists, technocratic sub-dividers and social engineers...the dominant space of any society (or mode of production)" (Lefebvre, 1991, p. 38-9). Therefore, for Lefebvre, those who conceive space and represent it in maps, diagrams, plans, models, images etc., reflect how power creates dominant discourses through the ways in which space is surveyed, surveilled, controlled, delimited, delineated and organised to meet particular endsas he states: "any representation is ideological if it contributes either immediately or 'mediately' to the reproduction of the relations of production. Ideology is therefore inseparable from practice" (Lefebvre, 1977, p. 29) and it "is the role of ideologies to secure the assent of the oppressed and exploited" (Lefebvre, 1996, p. 76);

- 'Spaces of representations' (lived space), which may be described as "mental inventions...that imagine new meanings or possibilities for spatial practices" (Harvey, 1990, p. 218). Lefebvre argues that this is "space as directly lived through its associations and images and symbols, and hence the space of 'inhabitants' and 'users'" Furthermore, "[t]his is the dominated-and hence passively experienced-space which the imagination seeks to change and appropriate. It overlays physical space, making symbolic use of its objects" 
(Lefebvre, 1991, p. 39). We therefore live in and through space made and controlled by others (those with power to shape, form and represent to us its appropriate use) and which we have to navigate to make 'sense' of and function in the world.

However, as human beings, as individuals and as social collectivities, we do not always do what we are told, act as we are supposed to or accept the limitations imposed by others. We subvert, imagine, inhabit, colonise and impose our own meanings, values and uses on space in creative and playful ways that can conflict and contest dominant forms and representations of space. There is thus a need for the time and space for fairs, festivals, fun and frolics, for play in which we share with others our sense of being and belonging, identity and culture, that expresses our underlying human condition our creativity, hopes and expectations.

The interlinked elements of his triadic analysis (spatial practices, representations of space and use of space), provide a theoretical structure for the analysis of modern, increasingly urban capitalism. One, Lefebvre argues, that is essential for understanding how the diverse factors salient to the experience of contemporary urban society (social structure, social action and social interactions, power, privilege and polemic) are not only framed in space but shaped, moulded, delimited and delineated by it. Lefebvre thus provides a means to deconstruct not only how dominant values and ideological parameters are impressed on, in and through space but also how we can make sense of the spaces that are made for us and that we use in everyday life. What is crucial is knowledge of how space is produced, by whom, for whom, for what functions, purposes, and to what ends etc. He argued that such knowledge of space provides the possibility of using and making space in more humane and just ways, to 'make' space to suit the needs and priorities, the values and meanings of not only capital but also the urban population at large. That is, spatial forms at various scales and sizes that are truly open and inclusive, that accommodate and encourage diversity and promote the creative and imaginative capacities and possibilities, hopes and aspirations that are necessary for sustainable, successful and healthy urban communities and populations.

To have true knowledge of the production of space one needs to understand the dynamic interaction and mutual interdependency between all three elements. Lefebvre's analysis of the interlinked elements of the production of urban space offers a way to see, read and understand how the city, landscape and architecture is produced and associated not only with living, with the experience of not just inhabiting a socio-spatial environment but also being actively involved in its creation, and thus with the possibility of changing it. For Lefebvre:

The long history of space, even though space is neither a 'subject' nor an 'object' but rather a social re- ality...must account for both representational spaces and representations of space, but above all for their inter-relationships and their links with social practice. (Lefebvre, 1991, p. 116)

Space is produced in a dynamic relationship between all three parts. There is thus a reciprocal relationship between the elements involved in its production.

For Lefebvre, under capitalism the element of his triad that has come to dominate the others is representations of space and reflects the needs and priorities of finance, of capital, of economic and political elites, of those with power. Space is produced and shaped for economic production and for social reproduction, and as "[s]pace is permeated with social relations: it is not only supported by social relations but is also producing and produced by social relations" (Lefebvre, 1991, p. 286). Space is produced as attempts to shape, manipulate, and dominate space well as the people and activities that are allowed or who have to use it. Dominant spatial forms are produced as the result not of competing ideas and values in modernity but ultimately by the imposition of the powerful who seek to control it in their own interests. However, to understand the fundamental importance of the production of space we must, as Hayden (1997) argues, see not only its complexity but also the conflicts and challenges that makes space the product of social relations: "human patterns impressed upon the contours of the natural environment....The story of how places are planned, designed, built, inhabited, appropriated, celebrated, despoiled and discarded. Cultural identity, social history, and urban design are here intertwined" (Hayden, 1997, p. 111).

\section{The Politics and Ideology of Space}

Lefebvre is well aware that current spatial forms and configurations in the modern urban are not spontaneous or come into being without a history. Space is not neutral, it is subject to the actions and operation of power in which the control, ownership and regulation of space permits some actions to occur whilst limiting or prescribing others. "Space has been shaped and moulded from historical and natural elements, but this has been a political process. Space is political and ideological" (Lefebvre, 1977, p. 341). Who owns, controls and regulates space, to what end, for what purposes and how this is achieved is crucial for understanding how modern urban conditions are created, how they change and how this impacts on the everyday lived experience of their populations. "Spatial and temporal practices are never neutral in social affairs. They always express some kind of class or other social content, and are more often than not the focus of intense social struggle" (Harvey, 1990, p. 239.) But this is not a one-way process. Space is subject to conflict over ownership, over meanings, values, uses, etc. and thus a terrain (for Lefebvre, a crucial battleground) in which social justice and equality are contested. 
The urban is the dominant spatial form of contemporary societies. The world is one that is increasingly urban with a global majority of people now living in towns and cities. How cities are planned, designed and built reflects ideas and ideologies concerned with organisation and structure, of control and order. It is not merely a material reality but like every other aspect of life involves the consumption of signs. They are represented to us in a variety of ways not least through and in the spatial forms we encounter in our daily lives that attempt to structure and regulate what is deemed as acceptable and appropriate use. Whilst Harvey's geographical materialism differs in some aspects, it is clear that he is builds on Lefebvre's analysis. For example, he states that:

Symbolic orderings of space and time provide a framework for experience through which we learn who or what we are in society....The common-sense notion that 'there is a time and a place for everything' gets carried into a set of prescriptions which replicate the social order by assigning social meanings to spaces and times. (Harvey, 1990, p. 214)

This is reminiscent of Lefebvre's identification of the dominance of representations of space under capitalism. This then is how we manage to function and survive in modern complex urban environments that have become increasingly ordered and regulated for directional or prescriptive purposes and primarily associated with commodification and the conditions of the market. Thus, the city, Lefebvre argues, is subject to the dominating power of representation rather than the possibility of free creative expression. The urban becomes the means by and through which capitalism survives. It is also where conflict and social change occur. Hegemonic values and meanings are imposed on those who live in cities through dominant representations. This has impact and influence on the lived experience and everyday use of space. Instead of being able to inhabit and use social, public or collective space freely we are forced to endure a habitat created by and for the needs of capital. Mitchell (1995) argues that the needs and priorities of increasingly global capital, through its various 'managing committees', seek to impose ways to limit and control spatial interaction as "one of the principal aims of the urban and corporate planners during this century. The territorial segregation created through the expression of social difference has increasingly been replaced by a celebration of constrained diversity" (Mitchell, 1995, p. 119). Representations of space (the power to organise, regulate, delimit and delineate space according to function, aims and priorities) dominate the lived experience of the everyday use of urban space.

The urban is increasingly subject to interventions aimed at order and control to ensure the most efficient and effective conditions for capital. For Lefebvre, this is a means and process by and through which power, capital and class were imposed and promulgated:
There is no getting around the fact that the bourgeoisie still has the initiative in its struggle for (and in) space....The state and each of its constituent institutions call for spaces-but spaces which they can then organise according to their specific requirements. (Lefebvre, 1991, p. 56)

The social and public spaces that make the lived experience of the city "a way of life" (Wirth, 1938) are progressively codified, regulated, surveilled and policed. This control over the form, function, use and accessibility of public and social spaces is important because we learn who we are and where we belong by how our lives are structured, ordered, regulated and controlled in time and space. That is how or if, when and where we are allowed to express our own values, aims, identities, dreams to claim or make space for ourselves.

Planning, policy and investment decisions, regeneration and redevelopment strategies, etc. may have both positive and negative impacts on the quality of life, on opportunities, for social relations and interactions, for access to services and social, economic and spatial resources. This is not a new phenomenon. The 'problem of cities' identified by municipal and national governments, by health and social reformers, was associated with attempts to mitigate the worst effects of rapid urbanisation and industrialisation in the nineteenth and early twentieth centuries. Foucault $(1977,1980)$ argued this was focused on the fear of the expanding exploited urban masses viewed as a threat to medical, moral and political stability. What resulted was the development of 'specialists of space' whose knowledge of space and of populations resulted in observation and surveillance as well as the development of new forms of architecture and urban design. Whilst Foucault identified the medical profession as being directly involved in the development of 'disciplinary spaces' (whether as schools, hospitals, asylums, prisons, etc.), Lefebvre recognised the importance of planners, architects and urban designers as crucial actors in the production of spatial forms and arrangements that reflected the ideological necessities and requirements of capital.

However, what has increasingly developed is a conflict between truly open and accessible public space and that of "other powerful interests at work to supplant genuinely public space with its privatised surrogates" (Sennett, 1990, p. xii). Ferrell (2001), Mitchell (1995, 2003) and Zukin (1995) have argued that this leads to the exclusion from public space of many groups deemed inappropriate to commercial, financial or exclusive priorities. For Lefebvre this reflects a need to understand what, how and why everyday life is important because it reflects key aspects of modern urban life:

Everyday life and modernity, the one crowning and concealing the other, revealing and veiling it. Everyday life is a compound of insignificances united in this concept, responds and corresponds to modernity, a 
compound of signs by which our society expresses and justifies itself and which forms part of its ideology. (Lefebvre, 1971, p. 24)

As neo-liberal global capitalism colonises more of the world so more towns and cities in an increasingly dominant urban world are subject to the planning and design strategies of capital that mould and shape their form to meet their own ends. Harvey $(2001,2007,2012)$ consistently argues that in part, this represents another phase in capitals' attempt to conquer and shape space for its own ends. What is produced as urban landscapes is a perpetual sameness, lacking much in the way of real choice or of individuality. The branded and bland homogeneity and uniformity of towns and cities everywhere is laced with an intolerance of different views, opinions or lifestyles that clash with the designed intentions of market economics, and, as proxies, state functionaries, planners, urban designers and architects. There is little room for criticism or for difference for as Lefebvre (2009) puts it:

Capitalist and neo-capitalist space is a space of quantification and growing homogeneity, a commodified space where all the elements are exchangeable and thus interchangeable; a police space in which the state tolerates no resistance and no obstacles. Economic space and political space thus converge toward the elimination of all differences. (Lefebvre, 2009, p. 192)

The right to claim, appropriate and use urban social and public space as it is made and remade according to potentially changing and conflicting priorities, needs, aspirations and goals of the population is an essential part of a vital healthy society. Similarly, Goheen (1998, p. 479) states: "[c]itizens create meaningful public spaces by expressing their attitudes, asserting their claims and using it for their own purposes. It thereby becomes a meaningful public resource". However, the right to access and use public space is increasingly subject to conditions, prescriptions and at times outright bans when the priorities of business and commerce are impacted. Mitchell (1995) has demonstrated that "[p]ublic space is the product of competing ideas about what constitutes that space-order and control or free, and perhaps dangerous, interaction-and who constitutes the 'public'" (Mitchell, 1995, p. 115).

Lefebvre's emphasis on the need to consider everyday uses and practices of space is a fundamental focus of his analysis and argument. It is also a need to re-empower everyday life to ensure opportunities for individual and collective wellbeing are accommodated and encouraged within public and social spaces. Lefebvre (1971) defines everyday life as:

Made of recurrences: gestures of labour and leisure, mechanical movements both human and properly mechanic, hours, days, weeks, months, years, linear and cyclical repetitions, natural and rational time, etc.: the study of creative activity (of production, in its widest sense) leads to the study of reproduction or the conditions in which actions producing objects and labour are reproduced, re-commenced, and re-assume their component proportions or, on the contrary, undergo gradual or sudden modifications. (Lefebvre, 1971, p. 18)

How then can planning and urban design accommodate such hopes and aspirations as well as critical knowledge of space that underpins it?

\section{The City as Oeuvre}

Space, as a habitat and which we inhabit in our everyday lives, is the product of history: "itself the outcome of past actions, social space is what permits fresh actions to occur, some serve production others consumption....Social space implies a great diversity of knowledge" (Lefebvre, 1991, p. 72). However, Lefebvre argues that space, and particularly the space of the modern city has become rationalised, functionalised and above all ideologically planned and designed. Thus architecture, urban design, planning etc. those spatial sciences that mould and shape and deliver forms of space are replete with the imposition of dominant values, ideals and priorities. City life was, as many urban theorists have commented (see, among others, Georg Simmel, as cited in Frisby \& Featherstone, 1997; Benjamin, 1979, 1999, 2002; Mumford, 1937; Wirth, 1938) one of chance encounter and interaction, of diversity and difference, of possibilities of seeing, learning, being open to new sensations and experiences. It is in the streets and other public spaces that the life of the city was first observed and analysed as signifier and site of modernity and where urban experience was distinguished from the traditional world view of the rural and the feudal.

The city and the urban in modernity were understood as the centre for excitement, dangerous and pleasurable interactions and experience. The affluent sought sensual novelties in new leisure opportunities whilst the poor sought respite, recreation and distraction from overcrowded and unhealthy housing and working conditions in the streets and public spaces of the city. The exploitative and unhealthy conditions at home and in the new industrial work spaces created opportunities and experiences in the city that reflected its diversity, variety and excitement as a living entity. For Lefebvre (1996, p. 75) "urban life suggests meanings, the confrontation of difference, reciprocal knowledge and acknowledgement (including ideological and political confrontation) ways of living, 'patterns' which coexist in the city". In contemporary cities that are increasingly planned, designed, regulated and policed, these possibilities of spontaneity and of being in space are in danger of being lost. They are replaced with increasingly banal and sterile urban spaces, 
produced, shaped and regulated to eliminate difference and secure an orderly space for the market, for commodification and for profit.

For Lefebvre, this was not how the city always was, nor how it could or should be. "The city must be a place of waste, for one wastes space and time; everything mustn't be foreseen and functional, for spending is a feast" (Lefebvre, 1987, p. 36.) Ancient and medieval cities were more than mere market places, more than sites for the accumulation of capital. They grew and developed according to the needs of their inhabitants who prioritised social and public spaces (the agora, forum, etc.) as a key feature and element of collective belonging and the shared experience of the town and the city. For Lefebvre, urban life and the city was once a living creative process which should again contain possibilities of such creative and collective being in space:

The city is itself 'oeuvre', a feature that contrasts with the irreversible tendency towards money and commerce, towards exchange and products....They do not only contain monuments and institutional headquarters, but also spaces appropriated for entertainments, parades, promenades, festivities. (Lefebvre, 1996, p. 66)

For Lefebvre, urban life and the city was once a living creative process, a work of art, and should contain again such possibilities of imaginative being, of creative everyday praxis, of space made by and for human experience.

We now live dominated by the privatisation of experience, of consumption, in planned, designed space, commodified and policed to ensure order, control and stability to meet the needs of the market and of capital. This is at the expense of a truly collective social and spatial solidarity and proximity, of a shared potentiality of creative experience of being together in space. Mattila (2002) argues that modern architecture and urban design was planned in the post-war era was based on the imposition of elitist ideas to meet functional ends for the greatest number. Postmodern planning and architecture reflected the cultural populism of entertainment and escape, reproducing and inventing representations and cityscapes of pleasure and amusement (see, Harvey, 1990; Scott \& Soja, 1996; Soja, 1996; Venturi, ScottBrown, \& Izenour, 1972). However, for Lefebvre (1971, p. 197), "everyday life, the social territory and place of controlled consumption, of terror-enforced passivity, is established and programmed". Our public places are increasingly organised to meet the functional ends of production, reproduction and consumption and in this era of a perpetual war on terror to ensure order and control, safety and security. Harvey adapts, extends and applies Lefebvre's analysis to argue that: "[t]he human qualities of the city emerge out of our practices in the diverse spaces of the city even as those spaces are subject to enclosure, social control, and appropriation by both private and public/state interests" (Harvey, 2012, p. 72)
Lefebvre viewed social and public space as crucial not only to healthy and humane cities but to a truly democratic and inclusive urban society. It is in what he calls the disorder of the street that change and possibility, the sharing of ideas, meanings and experiences, that epitomises the best of urban experience, one that should be open and accessible to all, providing a forum for exchange, interaction and of collective being. Lefebvre (2003) argues that the street

Serves as a meeting place (topos), for without it no other designated encounters are possible....The street is a place to play and learn. The street is disorder....This disorder is alive. It informs. It surprises....In the street...appropriation demonstrates that use and value can dominate exchange and exchange value. (Lefebvre, 2003, p. 18)

We can identify the ways in which the order and control of the city and the urban has led to an increasingly homogenised and sanitised experience of it as environment. The functionalisation and delimiting of space has led to the segregation of groups, classes as well as activities such as industry, housing, commerce and leisure. The prioritisation and dominance of traffic over walking reflects not only changes in consumption patterns but links to flows and circulation that negates or inhibits pedestrian movement and the opportunities for lingering in space. This undermines the street, public and social space as vital not only to urban culture but to the health and wellbeing of urban society. Public space is a medium and mode of communication and of play and the pleasure and possibility of being together with others. It needs must be social space. This idea of space as a facilitator and medium for play was explored by Stevens (2007) using a distinctly Lefebvrian approach in which he argued that playful forms of activity in urban public spaces provide "a way to better understand the relations between the design of the built environment, the special social conditions which characterize the city, and people's perceptions and behaviour" (Stevens, 2007, p. 196). Therefore, to live in an open, creative, democratic space of a truly inclusive urban society is one which encourages playful expression and communication, artistic and aesthetic interventions in, on and through urban space. It was activities and events that take place in the street and in other public and social space (parks, gardens, arcades, promenades, precincts, squares, etc.) that, for Lefebvre, was of crucial importance. The 'right to the city' is a claim to the right to inhabit space, to make and use and to be represented in and through public space.

\section{The Right to the City}

Lefebvre's corpus of work on space, the urban and everyday life views the urban as the dominant spatial form of modern capitalism. For Lefebvre, the Urban Revolution (Lefebvre, 2003) has created a second human nature that 
is based in and off and created by the city. 'True knowledge' of space, requires understanding of its interlinked constituent parts which, for Lefebvre, was crucial. Knowing how space is produced provides the means to change it, to democratise and radicalise it. Thus, for Lefebvre, the 'right' to make space was fundamental to any 'right to the city', to its inhabitation for 'useful play'. Lefebvre wrote The Right to the City (1996) not as a nostalgic and sentimental call for a return to the past but as a plea for a reinvigorated, more just and humane urban environment. He states that:

The right to the city is like a cry and a demand...[and]...cannot be conceived of as a simple visiting right or as a return to traditional cities. It can only be formulated as a transformed and renewed right to urban life. (Lefebvre, 1996, p. 158)

It is a claim for the right to inhabit, use and appropriate space. Purcell (2002) argues that the complexities surrounding what these rights are and who has them need to be considered and clarified nevertheless, Lefebvre's focus is on the governance, design and planning of space. To have a right to say how the city develops and changes, how it is formed, organised, regulated and ultimately used. It is recognition of the need to reassert the right of inhabitants and not merely the rights of those with power and capital, to produce, shape, and use space according to their needs, wants and desires. Whilst Jacobs (1961) argued earlier that cities survive and prosper when they are inclusive and diverse, Merrifield (2014), Harvey (2012) and Stavrides (2016) argue is that these need to be extended to a right to occupy and use space in everyday life as the basis for a renewed and invigorated 'urban commons'. Lefebvre (2006, p. 75) made a similar point: "urban life suggests meanings, the confrontation of difference, reciprocal knowledge and acknowledgement (including ideological and political confrontation) ways of living, 'patterns' which coexist in the city". Social and public space is and should be made and remade according to the potentially conflicting priorities, needs, aspirations and goals of all of its citizens and not merely those with money and power. There is a need to understand that everyday life is made of diverse practices, people and activities and to plan to accommodate them in inclusive space.

Lefebvre's trialectic suggests a means by which we can understand space and challenge the ideologies that are inherent in how space is represented to us (through designs, maps, plans, signage, etc.) that seek to embed dominant discourses of appropriate and permitted use. In our everyday lives through our imaginative use of space we invest meanings and create values attached to spaces and places that challenge and contest not only spatial formations and practices that are indicative of the production of space under capitalism but also open up possibilities for being in the city that reflects more humane, shared and communal values. Thus, Lefebvre's aim is to uncover and illuminate the hidden truths of how dominant representations, signs and 'accepted' codes embedded within spatial forms can be understood and contested. So far it has been argued that Lefebvre's emphasis is predicated on his understanding that:

The critique of everyday life involves a critique of political life in that everyday life...is profoundly related to all activities, and encompasses them with all their differences and their conflicts; it is their meeting place, their bond, their common ground. (Lefebvre, 1991, pp. 92, 97)

The diversity and experience of everyday life and the challenges inherent within a multifaceted social, economic and political world therefore requires the application of knowledge of the complexity of the production of space, its impacts and consequences on urban form, organisation and experience. This was fundamental to his approach of creating an understanding of the urban that addressed the imbalances, inequalities and injustices in its governance and the opportunities that were available or denied. It seeks to rebalance the priorities and elements involved in the production of space to ensure a more equitable one that empowers the imagination and everyday inhabitation of space.

\section{The Possibility and Promise of Planning}

The challenges and practices of planning, architecture and urban design as spatial sciences are to operate not merely as a means or tools for power and capital in the top-down creation of the built and designed environment but also to ensure it encompasses and includes the needs and priorities of all the population. There are examples of a more collaborative approach in assessing and incorporating communities in decision making and planning processes. John Friedmann (1987, 2011) and Patsy Healey (2006, 2007, 2008, 2015a, 2015b) have been long term advocates and proselytizers for approaches to planning that are variously called collaborative, dialogues, relational, community engagement, etc. Whilst these go a long way to theorise and applying a more inclusive perspective that does not impose 'command and control' over neighbourhoods they still seem in the minority. For Lefebvre what is essential is how we can engage in the production of our living and working spaces because: "[ $t$ ]o change life, to change society', these phrases mean nothing if there is no production of an appropriated space" (Lefebvre, 2009, p. 186). It is or should be incumbent on all those engaged in shaping the form, function and use of the urban in all modes, fields, levels and scales, wherever and however they practice, to include an overarching and inclusive understanding of not only what they do, who it serves but also to ensure that the impacts and consequences for access, inclusion, use, etc. are as wide as possible and not dominated by financial, economic or security issues only. This should 
also include an aesthetic dimension in which the appreciation of appearance and form is important to experience, what Mattila (2002) calls aesthetic justice. Whilst appearance is not necessarily the prime consideration of any development or project it should be assessed for appropriateness or fitness both to the surrounding environment as well as representing or reflecting the population subject to it. For example, planners and architects have on many occasions produced designs that destroyed or had severe negative impacts on existing communities (e.g., road and motorway networks cutting existing communities in half or isolating them; the demolition of historic architecture and spatial forms and their replacement with concrete grids). Similarly, the use and location of street furniture and signage can be an impediment to access or a danger to those with mobility or ability issues. In these and in the choice of designs, location, and scale there is a need to ensure appropriateness and wider community aspirations. Lefebvre considers this an important aspect of spatial thinking and practice that is fundamental to urban life:

As necessary as science, but not sufficient, art brings to the realisation of urban society its long mediation on life as drama and pleasure.... To put art at the service of the urban does not mean to prettify urban space with works of art. (Lefebvre, 2006, pp. 157,173)

This would also include not only public art installations, grand architectural monuments, facades, seminal designs in new materials, shapes and forms but also opportunities for informal art and cultural activities that use the street and public space as a living canvas and openair gallery for cultural expressions of identity. Zieleniec (2016) applies a specific Lefebvrian analysis to the everyday challenges, conflicts and contestation of urban aesthetics, functionalised and securitised space practiced by graffiti writers and street artists as they colonise, appropriate and adorn the streets of towns and cities throughout the world with an alternative aesthetic creating a different semiotic for reading the city.

Lefebvre's spatial theory emphasises that what is essential for true knowledge of space is an overarching understanding of its complex features and elements involved in its production. This should include ensuring that there are not only sufficient opportunities for social interaction but that the spaces and places for this to occur are integrated within any project or development. This forms the basis of Lefebvre's cry and demand that:

The right to the city...stipulates the right to meetings and gatherings..., the need for social life and a centre, the need and the function of play, the symbolic functions of space (close to what exists over and above that classified as such) because it...gives rise to rhetoric and which only poets can call by its name: desire. (Lefebvre, 2006, p. 195)
It is also crucial to his emphasis on the city being understood as an oeuvre, a living space, rather than merely an imposed functional habitat.

There is a need then to engage with the creative and imaginative potential of urban people and urban spaces. We need to ensure that the urban remains as a place of encounters, a focus and locus for communication and information, for meaningful interactions and for difference, diversity and for creative and surprising potential. As Harvey, after Lefebvre, argues: "the social spaces of distraction and display become as vital to urban culture as the spaces of working and living" (Harvey, 1985, p. 256). Planning and urban design was implicated by Lefebvre in the operation of power to create and shape an urban that operated primarily for the needs of capital at the expense of the needs of the majority. There are examples of where the intention redesign and plan a new landscape was a form of enlightened paternalism to improve the quality of life and experience of the urban. For example, Fraser (2011) provides a Lefebvrian critique of Cerda's Eixample in Barcelona which he describes as belonging to "the paradigm of bourgeois fragmentary science...[a] curious reification of the city" (Fraser, 2011, p. 90), representative of a form of environmental determinism in which the problems of urban life could be changed by changing the city's material form. Whilst planning theory and practice has changed in the United States and Europe (Taylor, 1998) from the mid-20thcentury and other parts of the world have adopted new approaches (Friedmann, 1987, 2005, 2011), similar abstract idealism are evident in post-World War II developments. Le Corbusier's (1923/1986, 1929/2000) ideas of high modernist functionalism of 'machines for living' influenced a generation of planners, architects and urban designers who employed his ideas in the development of high-rise housing, concrete office blocks and peripheral housing estates. As Wacquant (2007) has argued, hypermarginalisation has accompanied the spatial marginalisation of those excluded and disenfranchised by postindustrialism and neo liberal economics, whether in the black urban ghettoes of the United States of the French Banlieu. In the contemporary urban new developments include the expansion the securitised compounds of 'gated communities', as well as what Garreau (1992) has called the "new urban frontier" of edge cities. These represent new design and planning opportunities that primarily focus on security and as a consequence an increasing racial and class homogenisation based on fear of difference and diversity.

As a humanist Marxist, Lefebvre consistently argued for the need to include an analysis of how space is produced, by whom for whom. He was not a reductionist materialist in that he was aware and celebrated the dissonances and spontaneity of everyday life and culture was as important as the economic base. However, there remains a need to question who benefits in the new urban designs and planning projects. There are many contemporary examples of urban regeneration schemes whose 
priority is the pursuit of profit and which leads to the exclusion, marginalisation, alienation and disenfranchisement of many communities and groups. They reflect a continuing tendency to apply top-down plans, imposed design or rules and restrictions on access to and use of public and social space. The redevelopment of cities in post-second world war Europe led to the creation of peripheral housing estates, tower block residential solutions to mass housing needs and the accommodation of the car as the primary means of transport. This led to large sections of the population becoming isolated and alienated within their segregated communities, increasingly ostracised and penalised by lack of opportunities when periodic economic crises led to the end of industrial employment. Social segregation coupled with and magnified by spatial segregation. It also led to many being excluded or dispossessed from the city centre as a hub of cultural and social activity through processes of regeneration which have turned so many into consumerist and gentrified havens only for those with the economic means to enjoy them. There is scope, a necessity perhaps, to revisit Lefebvre's spatial theory to reinvest the aims and goals of planning as the making of spaces and places concerned not least with the requirements of those who live, work and play in them. Whilst many spatial theorists have, a mentioned above, sought to consult and cooperate in inclusive practices, all too often this is not the case. There remains a need for practioners of planning and urban design, as the science and art of making space, to acknowledge its ideological roots, as Lefebvre discussed. Serving power, money and capital through the construction of spaces that function to ensure control, regulation can lead to social engineering through the production and segregation of space. Mitchell (1995) wrote of the potential for conflict in and over not only the uses of public space but the meanings and values attached to it:

Whatever the origins of any public space, its status as 'public' is created and maintained through the ongoing opposition of visions that have been held, on the one hand by those who seek order and control and, on the other, by those who seek places for oppositional political activity and unmediated interaction. (Mitchell, 1995, p. 115)

Thus, planning has at times served to segregate and marginalise, delimit and exclude as much as it has opened up avenue for an enhanced and expanded social life. However, there are possibilities and potentials in embracing an understanding, engagement and intervention in urban space which sees space as a social product, a creation of particular concatenations of circumstances with potential inscribed in their form for all. Instead of ideological and institutionalised discourses of privileged power that seeks to limit differences by homogenising and standardising forms and uses of public space a more democratic and holistic approach can be achieved and employed. This is what Lefebvre's spatial theory offers. A critical and reflective analysis of the complexity of space, that is inclusive and empowering. This is not merely adding to planning law, rules and regulations. It is not just ensuring that 'consultation' is a post-facto tick-box approval for plans already agreed. It is the incorporation of the complexity of understanding that the production of space needs must include those who are subject to its form, function and design. This could and should include from the beginning to the end of the process those who will be subject to, be enforced to endure or live with the results of urban plans and designs. That is, 'the right to city' is the right to be incorporated within planning practices at all levels: from the street, neighbourhood and community, to the city, region and state. It is a challenge to make space more inclusive, open and representative of the needs, wishes, aspirations and desires of all who use (and potentially misuse) public and social space. There must be the opportunity to ensure that we can inhabit a world that includes our own praxis, meanings, values, signs and symbols, art and culture and not merely be forced to endure a habitat created for and imposed on us by those with power. This, I would argue, reflects Lefebvre's claim to the right to the city' which "stipulates the right to meetings and gatherings..., the need for social life and a centre, the need and the function of play, the symbolic functions of space" (Lefebvre, 1996, p. 195), as opposed to the functional requirements of capital and business. Cities must be planned and designed for people as humane spaces and not just profit.

\section{Acknowledgments}

Thanks to the three anonymous reviewers who provided insightful and helpful comments, suggestions and advice and to the editors of the journal for their forbearance and support through the writing, editing and submission process.

\section{Conflict of Interests}

The author declares no conflict of interests.

\section{References}

Benjamin, W. (1979). One way street and other writings. London: Verso.

Benjamin, W. (1999). Illuminations. London: Pimlico.

Benjamin, W. (2002). The arcades project. Cambridge, MA: Harvard University Press.

Coleman, N. (2015). Lefebvre for architects. London: Routledge.

Elden, S. (2001). Politics, philosophy, geography: Henri Lefebvre in recent Anglo-American scholarship. Antipode, 33(5), 809-825.

Elden, S. (2004). Understanding Henri Lefebvre. New York, NY: Continuum.

Elden, S., Lebas, E., \& Kofman, E. (Eds.). (2003). Henri Lefebvre: Key writings. New York, NY: Continuum. 
Ferrell, J. (2001). Tearing down the streets: Adventures in urban anarchy. Basingstoke: Palgrave.

Foucault, M. (1977). Discipline and punish. London: Penguin.

Foucault, M. (1980). Power/knowledge: Selected interviews and other writings (1972-1977). London: Harvester Wheatsheaf.

Fraser, B. (2011). Henri Lefebvre and the Spanish urban experience: Reading the mobile city. Lewisburg, PA: Bucknell University Press.

Friedmann, J. (1987). Planning in the public domain: From knowledge to action. Princeton, NJ: Princeton University Press.

Friedmann, J. (2005). China's urban transition. Minneapolis, MN: University of Minnesota Press,

Friedmann, J. (2011). Insurgencies: Essays in planning theory. London: Routledge.

Frisby, D., \& Featherstone, M. (1997). Simmel on culture. London: Sage.

Garreau, J. (1992). Edge City: Life on the new frontier. Peterborough: Anchor Books.

Goheen, P. G. (1998). Public space and the geography of the modern city. Progress in Human Geography, 22(4), 479-496.

Harvey, D. (1978). The urban process under capitalism: A framework for analysis. International Journal of Urban and Regional Research, 2(1/3), 101-31.

Harvey, D. (1985). Consciousness and the urban experience. Oxford: Basil Blackwell.

Harvey, D. (1990). The condition of postmodernity. Cambridge: Blackwell.

Harvey, D. (2001). Spaces of capital: Towards a critical geography. Edinburgh: Edinburgh University Press.

Harvey, D. (2007). A brief history of neoliberalism. Oxford: Oxford University Press.

Harvey, D. (2012). Rebel cities. London: Verso.

Hayden, D. (1997). Urban landscape history: The sense of place and the politics of space. In P. B. Groth (Ed.), Understanding ordinary landscapes (pp. 111-133). London: Yale University Press.

Healey, P. (2006). Collaborative planning: Shaping places in fragmented societies. London: Palgrave Macmillan.

Healey, P. (2007). Urban complexity and spatial strategies: A relational planning for our times. London: Routledge.

Healey, P. (2008). Civic engagement, spatial planning and democracy as a way of life. Planning Theory \& Practice, 9(3), 379-414.

Healey, P. (2015a). Citizen-generated local development initiative: Recent English experience. International Journal of Urban Sciences, 19(2), 109-118.

Healey, P. (2015b). Civil society enterprise and local development. Planning Theory and Practice, 16(1), 11-27.

Jacobs, J. (1961) The death and life of great American Cities. New York, NY: Random House.

Kipfer, S. (2002). Urbanization, everyday life and the survival of capitalism: Lefebvre, Gramsci and the prob- lematic of hegemony. Capitalism Nature Socialism, 13(2), 117-149.

Le Corbusier. (1986). Towards a new architecture. New York, NY: Dover Publications. (Original work published 1923)

Le Corbusier. (2000). The city of tomorrow and its planning. New York, NY: Dover Architecture. (Original work published 1929)

Lefebvre, H. (1971). Everyday life in the modern world. London: Harper Torchbooks.

Lefebvre, H. (1977). Reflections on the politics of space. In R. Peet (Ed.), Radical geography (pp. 339-352). London: Methuen and Co.

Lefebvre, H. (1987). An interview with Henri Lefebvre. Environment and Planning D: Society and Space, 5(1), 27-38.

Lefebvre, H. (1991). The production of space. Blackwell: Oxford.

Lefebvre, H. (1995). Introduction to modernity. London: Verso.

Lefebvre, H. (1996). Writing on cities. London: Blackwell.

Lefebvre, H. (2003). The urban revolution. Minneapolis, MN: Minnesota University Press.

Lefebvre, H. (2004). Rhythmanalysis: Space, time and everyday life. London: Continuum.

Lefebvre, H. (2009). State, space, world: Selected essays. Minneapolis, MN; London: University of Minnesota Press.

Lefebvre, H. (2014). Critique of everyday life. London: Verso.

Lefebvre, H., \& Levich, C. (1987). The everyday and everydayness. Yale French Studies, 73, 7-11.

Mattila, H. (2002). Aesthetic justice and urban planning: Who ought to have the right to design cities? Geojournal, 58(2/3), 131-138.

Merrifield, A. (1993). Place and space: A Lefebvrian reconciliation. Transactions of the British Institute of Geographers, 18(4), 516-531.

Merrifield, A. (2006). Henri Lefebvre: A critical introduction. London: Routledge.

Merrifield, A. (2014). The new urban question. London: Pluto Press.

Mitchell, D. (1995). The end of public space? Peoples park, definitions of the public, and democracy. Annals of the Association of American Geographers, 85(1), 108-133.

Mitchell, D. (2003). The right to the city. New York, NY: Guilford.

Mumford, L. (1937). The culture of cities. New York, NY: Harcourt.

Purcell, M. (2002). Excavating Lefebvre: The right to the city and its urban politics of the inhabitant. GeoJournal, 58, 99-108.

Scott, A. J., \& Soja, E. W. (Eds.). (1996). The city: Los Angeles and urban theory at the end of the twentieth century. Berkeley, CA: University of California Press.

Sennett, R. (1990). The conscience of the eye: The design and social life of cities. London: Faber \& Faber. 
Shields, R. (1999). Lefebvre, love and struggle. London: Routledge.

Soja, E. (1996). Thirdspace: Journeys to Los Angeles and other real-and-imagined places. Oxford: Basil Blackwell.

Stanek, L. (2011). Henri Lefebvre on space. Minneapolis, MN: Minnesota University Press.

Stavrides, S. (2016). Common space: The city as commons. London: Zed Books.

Stevens, Q. (2007). The ludic city. Abingdon: Routledge.

Taylor, N. (1998). Urban planning theory since 1945. London: Sage.

Venturi, R., Scott-Brown, D., \& Izenour, S. (1972). Learn- ing from Las Vegas. Cambridge, MA: MIT Press.

Wacquant, L. (2007). Urban outcasts: A comparative sociology of advanced marginality. Cambridge: Polity Press.

Wirth, L. (1938). Urbanism as a way of life. American Journal of Sociology, 44(1), 1-24.

Zieleniec, A. (2007). Space and social theory. London: Sage.

Zieleniec, A. (2016) The right to write the city: Lefebvre and graffiti. Environnement Urbain/Urban Environment, 10, Retrieved from http://eue.revues.org/ 1421

Zukin, S. (1995). The cultures of cities. London: Blackwell.

\section{About the Author}

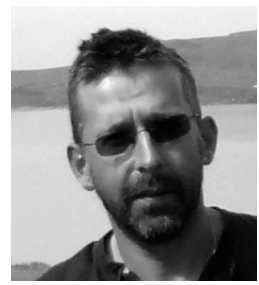

Andrzej Zieleniec is an interdisciplinary Lecturer and currently Programme Director for Liberal Arts at Keele University. His research and teaching interests focus on the interface between space, society and culture, particularly in the way in which our lived environment is moulded and shaped by social practices, either those imposed by power or those challenged or colonised by the everyday practices of a range of social groups. He has published two monographs Space and Social Theory (2007, Sage) and Park Spaces: Leisure Culture and Modernity (2013, Scholars Press). 